\title{
Profiling of Indoor Plant to Deteriorate Carbon Dioxide Using Low Light Intensity
}

\author{
Mohd Mahathir Suhaimi Shamsuri ${ }^{1, \dagger}$, A.M. Leman ${ }^{1}$, Azian Hariri ${ }^{2}$, K.A Rahman ${ }^{2}$, M.Z.M \\ Yusof $^{2}$, and Azizi Afandi ${ }^{2}$ \\ ${ }^{1}$ Faculty of Engineering Technology, Universiti Tun Hussein Onn Malaysia (UTHM), \\ 86400, Parit Raja, Batu Pahat,Johor Malaysia. \\ ${ }^{2}$ Faculty of Mechanical and Manufacturing Engineering, Universiti Tun Hussein Onn Malaysia \\ (UTHM), 86400, Parit Raja, Batu Pahat,Johor Malaysia.
}

\begin{abstract}
Reasonable grounds that human needs the plants because their abilities reduce carbon dioxide $\left(\mathrm{CO}_{2}\right)$. However, it is not constantly human with the plants, especially in the building. This paper intends to study the abilities of seven plants (Anthurium, Dumb Cane, Golden Pothos, Prayer Plants, Spider Plant, and Syngonium) to absorb $\mathrm{CO}_{2}$ gas. The research was conducted in chambers (one cubic meter) with temperature, lux intensity and $\mathrm{CO}_{2}$ concentration at $25 \pm 10 \mathrm{C}, 300 \mathrm{lux}$, and $450 \pm 10 \mathrm{ppm}$. Before experimental were carried out, all plants selected should be assimilated with an indoor setting for performance purpose, and the experiment was conducted during daytime (9 am-5 pm). The experiments run in triplicate. Based on the results that are using extremely low light that ever conducted on plants, only Spider Plants are not capable to absorb $\mathrm{CO}_{2}$, instead turn up the $\mathrm{CO}_{2}$ rate during respiration. Meanwhile, Prayer Plant is the most plant performed with $\mathrm{CO}_{2}$ reduction is $7.62 \%$, and this plant also has equivalent results in triplicate study based on an ANOVA test with significant value at 0.072 . The conclusions of this research, only Spider Plant cannot survive at indoor condition with extremely low light for plants live and reduce $\mathrm{CO}_{2}$ concentration for indoor air quality (IAQ). The rate of 300 lux is a minimum light at indoor that are set by the Department of Occupational Safety and Health (DOSH, Malaysia).
\end{abstract}

\section{Introduction}

Carbon dioxide $\left(\mathrm{CO}_{2}\right)$ is one of a contaminant when elevated at higher concentration [1]. Based on the recommendations of ASHRAE (American Society of Heating, Refrigerating, and Air-Conditioning Engineers), limit $\mathrm{CO}_{2}$ concentration in indoor is $1000 \mathrm{ppm}$ [2]. Normally, $\mathrm{CO}_{2}$ in the building due to human respiration, and this gas has a significant effect on human [3]. If the $\mathrm{CO}_{2}$ concentration is not controlled, it will cause a headache, loss of focus, and unconsciousness on human [4]. $T^{\dagger}$ herefore, indoor air quality (IAQ) should be preserved wisely. Many efforts are made to achieve IAQ for both technical and

${ }^{\dagger}$ Corresponding author: mohd_mahahir@rocketmail.com 
management fields [5]. However, every study conducted to enhance air quality must be concerned about energy usage. Around $40 \%$ of the total global energy consumed by buildings, and it is expected to be increased by $50 \%$ in the 2030 [6]. Meanwhile, buildings in Malaysia (residential and commercial building) use about $48 \%$ of the total energy that produced by responsible bodies (Tenaga Nasional Berhad) [7].

Based on Malaysian Ministry of Energy, Green Technology and Water (KeTTHA) in 2015 strongly recommended to reduce the energy consumption for improving the quality of life and preserving natural resources and the environment. Indoor plants seem an alternative solution in response to the suggestion. Through to studies by former researchers claim that indoor plants are capable to serve as bio-filtration $[8,9,10,11,12,13]$. It is interesting to purify the indoor air using a minimum or without energy, and this would be very beneficial to humans.

However, indoor plants originally came from the forest, and the environments are different compared to the indoor. The significant difference of environment between indoor and outdoor, that effect on plant growth is lighting and temperature. Based on DOSH (Department of Safety and Health Malaysia), propose that lighting limit for indoor building is ranging from 300 lux to 700 lux [14], meanwhile, light intensity on daylight is more than 1000 lux. Besides that, the allowable temperature by ICOP (Industry Code of Practice) in an office building is $230^{\circ} \mathrm{C}$ to $260^{\circ} \mathrm{C}$ [15], while Malaysian temperature at noon exciding $300^{\circ} \mathrm{C}[16]$.

Light is the energy source for the plant to do photosynthesis process [17]. Devkota claim that certain plant needs a medium light (not too high or too low) to get optimum growing [18]. Moreover, the right concentration of light imposed on the plant will cause photosynthesis process perform preferable [19]. Other than that, blue and red light is the color that plants strongest response for photoperiod growth and sprout, yellow and green light will cause the color reflected back into space air [20].

In the meantime, the temperature is also one of factors that can impact on plant growth. High temperature is usually stress for plants, restricting growth, and will damage the photosynthetic system [21]. Whilst, low temperature also makes the plant in photoinhibition condition, limiting the productivity and geographical distribution of many species, including important agricultural crops [22,23]. Because of that, optimum temperature should be imposed on the plant environment to maximize the photosynthetic rate [24].

Nevertheless, to meet the desire to improve air quality using plants, aptitude tests in the building to plant life should be carried out. Based on former researchers such as Quero and Torpy, they had allowed the plants assimilated at indoor first (for certain periods) before the next test conducted $[25,26]$. Assimilation process will specify whether the plant will survive in the building or not, since rate of light and temperature at indoor very low compare to outdoor. Certain plants are able to down-regulate their photosynthetic apparatus when they are assimilated to yet lower light and temperature conditions [19]. Figure 1 show types of indoor plant in this study.

\section{Method And Materials}

\subsection{Indoor Plant Material}

Indoor ornamental plants were selected based on the existence in the local study area (Batu Pahat, Johor). The choice of plants is also through to the recommendation by former researchers such as Wolverton and Omar-Hor [27,28]. All plants grow in a pot-sized of 17 
$\mathrm{cm}$ diameter and $25 \mathrm{~cm}$ height, and pot mix ration is 2:2:1 (garden soil, compost, and perlite). Other than that, all plant ages that involved in this study is one year.

Before experimental were conducted, all plants involved must be assimilated with the indoor environment for at least two months, as recommended by Drozak and Torpy [29, 26]. In assimilation process, allowing plants to tolerate with indoor environment, where lighting and temperature is different compared to their original habitation. Light intensity during assimilated process is 300 lux, because this is minimum rates that are prescribed by the Department of Occupational Safety and Health [14]. Meanwhile, the temperature was fixed at 250C due to direction from the Prime Minister Office [30].
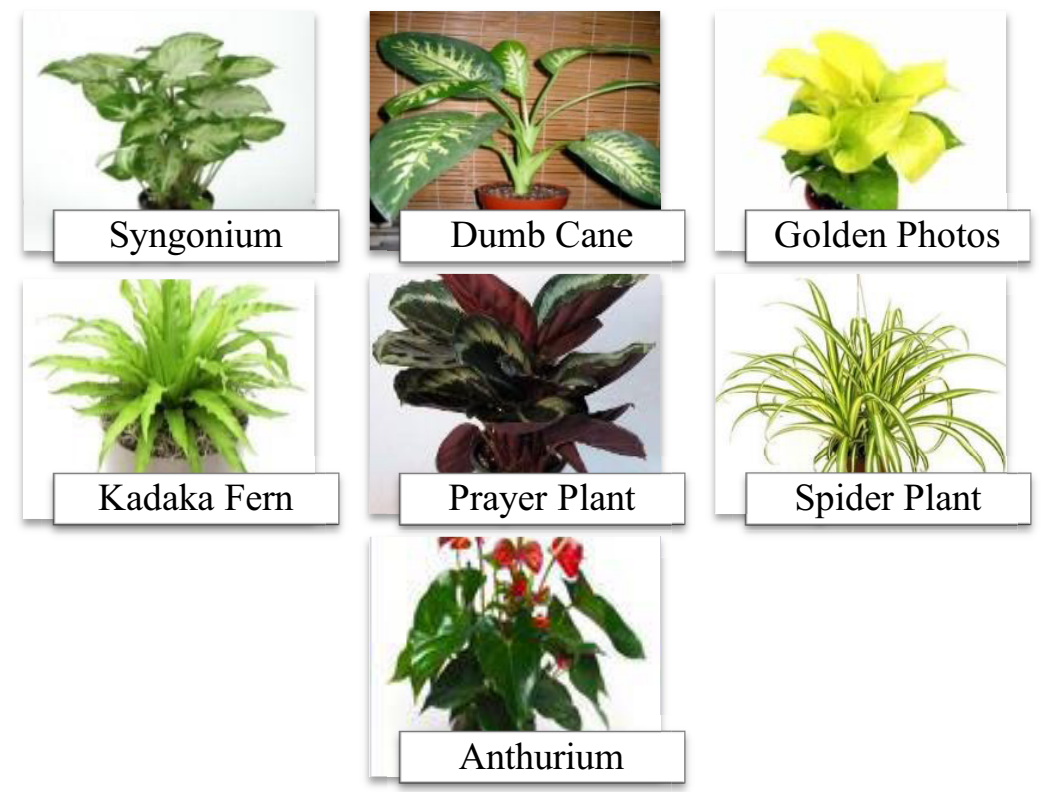

Fig. 1. Types of Indoor Plant [28, 29].

\subsection{Method}

Basically the method for this study based on report that is published by Australian Horticulture in the year 2011. In addition, this study also refers to other former researchers $[10,31,32]$ as a method guideline, to ensure there is no doubt on the results. Every plant will be tested individually in one cubic meter chamber to analysis their performance to reduce $\mathrm{CO}_{2}$ level. The reason why this control test is carried out because the plant also produces $\mathrm{CO}_{2}$ [33], and before plants used in real situations, the researcher must determine the abilities of every single plant to reduce $\mathrm{CO}_{2}$ by its own (without any other source of $\mathrm{CO}_{2}$ ).

Besides that, adhesive foam-plastic insulation tape was used to provide airtight seal on the top of the chamber, and $12 \mathrm{~V}$ DC fan inside the chamber to promote complete mixing. The temperature during the test was kept at $250 \mathrm{C} \pm 10 \mathrm{C}$ to comply with Industrial Code Of Practice On Indoor Air Quality and Prime Minister Office, Malaysia [15, 30]. Meanwhile, the intensity of light that are provided along the tests is 300 lux, because researcher want to investigate the abilities of plants to reduce $\mathrm{CO}_{2}$ gas (after plants was assimilated at indoor with the same rate of 300 lux) in the chamber. 
Artificial lighting was provided by fluorescent bulbs that are placed at outside the chamber, about $30 \mathrm{~cm}$ from center of the plant. Apart from that, a portable IRGA TSI IAQ meter also used to monitor the $\mathrm{CO}_{2}$ concentration in the chamber, and was set to record $\mathrm{CO}_{2}$ reading at 5 minute intervals. All whole potted plant chamber trials were performed at ambient of $\mathrm{CO}_{2}$ level at $450 \pm 10 \mathrm{ppm}$, where this being normal rate of indoor. Plants were tested individually during office hours from 9.00 am to $5.00 \mathrm{pm}$, and this study involving three plants for each species (triplicate study).

\subsection{Data Analysis}

Data were analyzed by One Way Analysis of Variance (ANOVA) using the Statistical Program for Social Sciences (SPSS) versions 20 for the significant analysis at $\alpha=0.05$. Mean of data also important to analyze to support the analysis.

\section{Results and Discussion}

Figure 2 till Figure 8 shows all finding results based on graph illustration. Each graph is based on triplicate experiments. The findings also use the lowest light intensity that ever used on plants to reduce $\mathrm{CO} 2$ level. Generally, output graphs ( $\mathrm{CO} 2$ concentration) for all types of plant are fluctuated, it is because plants also produce $\mathrm{CO} 2$ during respiration process [24]. Respirations on plants occur for both dark and light condition, and do not like photosynthesis, which only requires the presence of light [33]. Photosynthesis and respiration process can be attributed with light intensity. According to Irga, found that photosynthesis will more perform rather than respiration during high light intensity, that mean $\mathrm{CO} 2$ absorption will improve without fluctuate [26]. This research uses low light intensity (300 lux) because to comply the minimum of light intensity at indoor [14].

Table 1 shows details about CO2 reduction by each plant species. Prayer Plant is a plant that most perform to reduce $\mathrm{CO} 2$ concentration by $7.62 \%$, followed by Dumb Cane (7.42\%), Golden Pothos (6.5\%), Kadaka Fern (4.65\%), Syngonium (3.1\%) and Anthurium $(1.1 \%)$. In order to support percentage reading of $\mathrm{CO} 2$ reduction, average of $\mathrm{CO} 2$ reading also needed. This average is the result from 96 point reading of $\mathrm{CO} 2$ (5 minute interval from 8 hours test duration) which was taken in the chamber along with the plant.

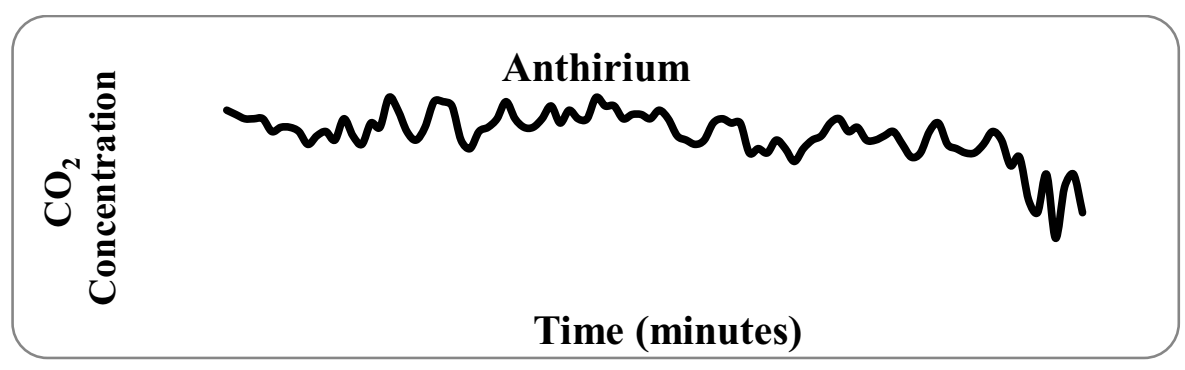

Fig. 2. Graph of $\mathrm{CO}_{2}$ absorption by Anthurium. 


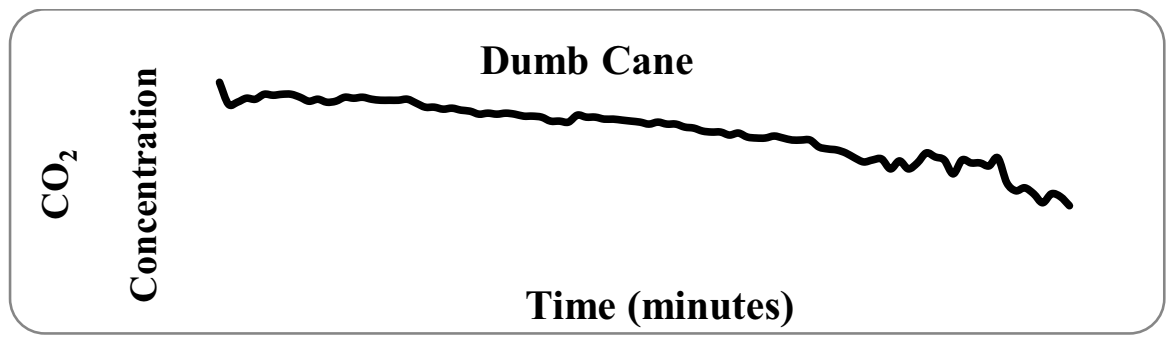

Fig. 3. Graph of $\mathrm{CO}_{2}$ absorption by Dumb Cane.

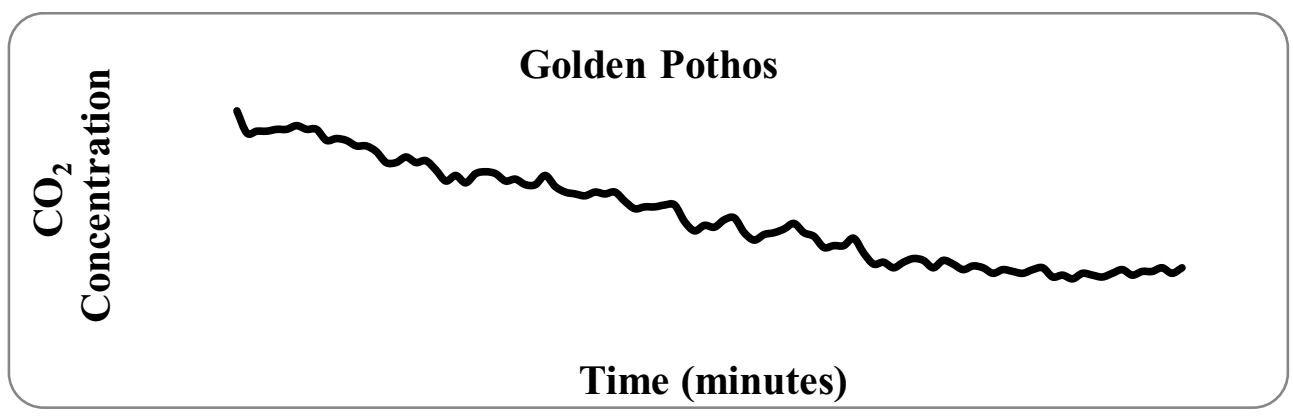

Fig. 4. Graph of $\mathrm{CO}_{2}$ absorption by Golden Pothos.

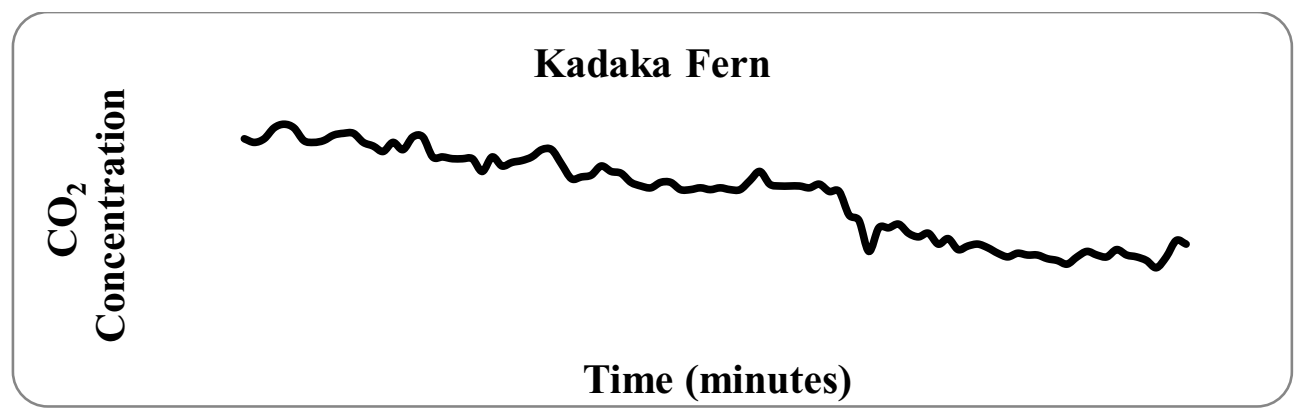

Fig. 5. Graph of $\mathrm{CO}_{2}$ absorption by Kadaka Fern.

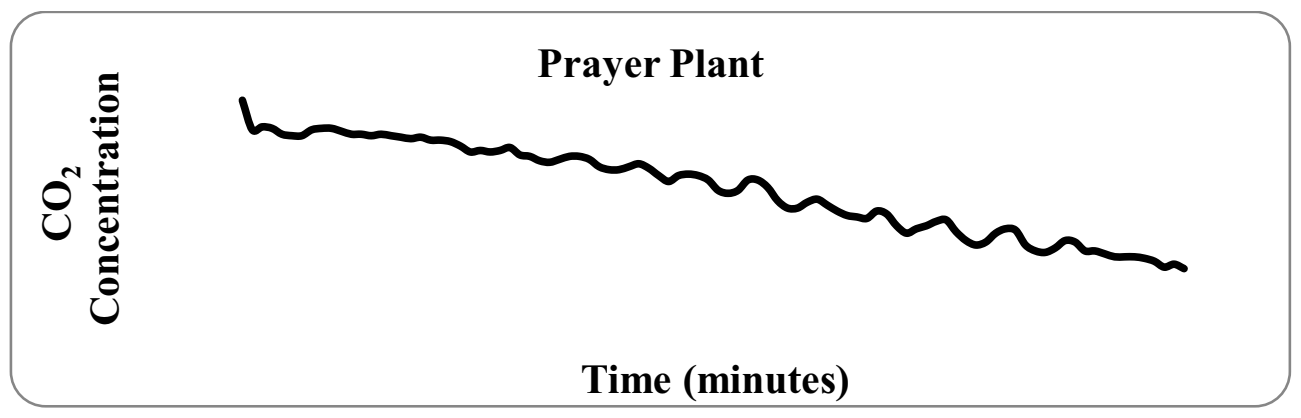

Fig. 6. Graph of $\mathrm{CO}_{2}$ absorption by Prayer Plant. 


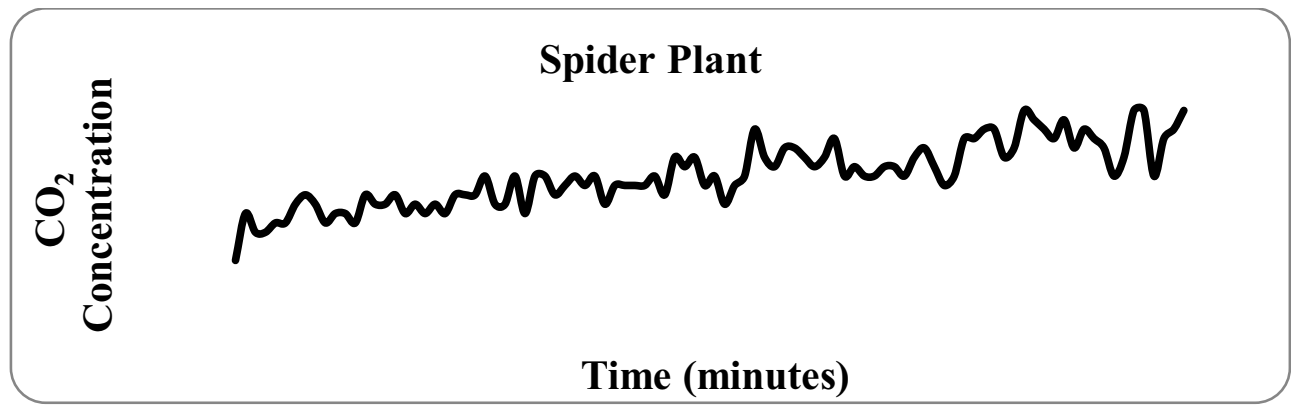

Fig. 7. Graph of $\mathrm{CO}_{2}$ absorption by Spider Plant.

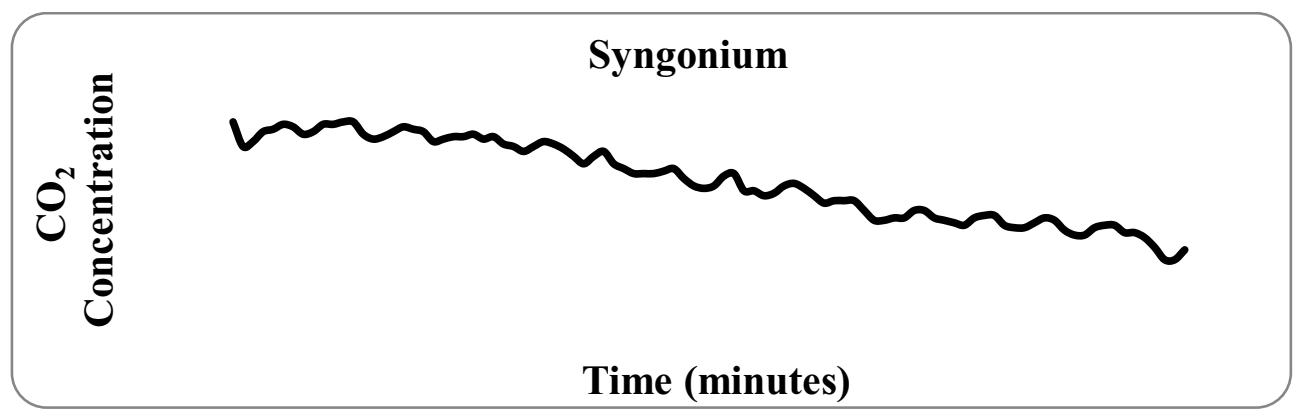

Fig. 8. Graph of $\mathrm{CO}_{2}$ absorption by Syngonium.

All average value except the Spider Plant is lower than initial reading, and that means it supports the fact that the plants in this study were able to reduce $\mathrm{CO} 2$ levels even in low light conditions. $\mathrm{CO}_{2}$ reduction by Anthurium is the fewest compare to others, and 300 lux light intensity seems the value of light compensation point (LCP) for the Anthurium whole potted plant. LCP is light level that photosynthesis and respiration occur at the same rate (have no $\mathrm{CO} 2$ reduction) [34]. Meanwhile, $\mathrm{CO} 2$ concentration in Spider Plant during this study is increasing around $1.1 \%$. Failure Spider Plant to reduce levels of CO2 is due to lack of concentration levels of light that should have been imposed on the plant. If the intensity of light applied to a plant does not help in the process of photosynthesis, the $\mathrm{CO} 2$ concentration will increase [19].

Table 1. Details of reducing $\mathrm{CO} 2$ by each plant species.

\begin{tabular}{|l|c|c|c|c|c|}
\hline Type of plant & $\begin{array}{c}\text { Initial } \mathrm{CO}_{2} \\
\text { reading } \\
(\mathrm{ppm})\end{array}$ & $\begin{array}{c}\text { Final } \mathrm{CO}_{2} \\
\text { reading } \\
(\mathrm{ppm})\end{array}$ & $\begin{array}{c}\text { Average } \mathrm{CO}_{2} \\
\text { reading for 96 } \\
\text { point (ppm) }\end{array}$ & $\begin{array}{c}\mathrm{CO}_{2} \\
\text { reduction } \\
(\%)\end{array}$ & $\begin{array}{c}\text { ANOVA } \\
\text { sig. level at } \\
\alpha=0.05\end{array}$ \\
\hline Anthurium & 452 & 447 & 449.86 & 1.1 & 0.061 \\
\hline Dumb Cane & 453.33 & 419.67 & 439.91 & 7.42 & 0.003 \\
\hline Golden Pothos & 454 & 425.67 & 434.76 & 6.5 & 0.056 \\
\hline Kadaka Fern & 458.67 & 437.33 & 447.2 & 4.65 & 0.064 \\
\hline Prayer Plant & 454.67 & 420 & 434.05 & 7.62 & 0.072 \\
\hline Spider Plant & 455.33 & 458.33 & 458.25 & -1.1 & 0.000 \\
\hline Syngonium & 454 & 435 & 444.1 & 3.1 & 0.045 \\
\hline
\end{tabular}

In this study, the researcher uses three plants for every species to conduct the experiments. By doing so, researcher must know about the significance for every plant in 
the same species through to change rate of $\mathrm{CO} 2$ during this study. Because of that, researcher was used ANOVA technique in SPSS to find the significant for every plant in the same type. This solves problem recommended by Liu [32]. In ANOVA, to determine the significant between several groups, it depends on alpha $(\alpha)$ value. If alpha is greater than 0.05 , it means that each group has a significant data; otherwise, if alpha is smaller than 0.05 , it means that each group has no significant data [35]. Based on the Table 1, only Anthurium, Golden Pothos, Kadaka Fern, and Prayer Plant have significant value more than 0.05 , where the value is $0.061,0.056,0.064$, and 0.072 . From this study that use low light level, can be seen through the data, Prayer Plant performs well, with the highest CO2 reduction, and have a higher level of significance. Unfortunately, Dumb Cane and Syngonium have significant value that lowers than 0.05 , where the value is 0.003 and 0.045 , and this is what is being said by Schornack and Wang that the testing of microbiology plant is intractable [36]. Even Dumb Cane and Syngonium have no significant data, but, each of plant from both species capable to reduce $\mathrm{CO}_{2}$ (through to data finding). Meanwhile, significant value for Spider Plant is zero, and that means every plant for this species really different. From observations of researchers, found that Spider Plant has difficulty living in the building, where, in the low light, it makes the plant wither and fall leaves.

\section{Conclusion}

The focus of this study is to identify seven plant species that might function well to absorb $\mathrm{CO}_{2}$ at indoor condition. Nevertheless, there may be constraints by plants to perform due to light factor, where indoor lighting is much lower compared to planting origin. This clearly when looking at Spider Plant that had no $\mathrm{CO}_{2}$ reduction on it, instead increase the value. However, certain plants can tolerate with indoor condition after assimilation process is conducted on plants. As evidence, types of plants such as Anthurium, Dumb Cane, Golden Pothos, Kadaka Fern, Prayer Plant, and Syngonium capable to survive under indoor condition (with 300 lux light intensity), and even able to slightly decrease the concentration of $\mathrm{CO}_{2}$ in the chamber. Overall in this experiment, it was found type of Prayer Pant is the most perform plant compare to others (based on the amount of $\mathrm{CO}_{2}$ reduction, and the significant between plants).

The authors would like to thank the Ministry of Higher Education Malaysia through the funding supported (MyBrain15). Thank you to Universiti Tun Hussein Onn Malaysia (UTHM) and the Centre for Graduate Studies - UTHM.

\section{References}

1. M. Mahathir, J. Sch. Health, 12, 2 (2015)

2. Standard, A. S. H. R. A. E., 55: Thermal Environmental Conditions for Human Occupancy American Society of Heating, (Atlanta, USA, 1992)

3. P.N. Bierwirth, www.researchgate.net (2015).

4. Occupational Safety and Health Administration (OSHA), Indoor Air Quality in Commercial and Institutional Buildings, (Washington, 2011)

5. A.J. Respir, Am. J. Respir. Crit. Care Med., 180, 8 (1997)

6. R.M. Zin, J. Teknol., 70, 7 (2014)

7. R. Saidur, H.H. Masjuki, Int. J. Mech. Mater. Eng., 3, 1 (2008)

8. Z. Wang, Thesis, Syracuse University (2011)

9. Mahathir, A.M. Leman, H. Shafii, The 3rd Scientific Conference on Occupational Safety and Health-Sci-Cosh (2014) 
10. U. Shome, Thesis, The University of Guelph (2004)

11. B.C. Wolverton, Interior Landscape Plants For Indoor Air Pollution Abatement, (Washington, 1989)

12. J. Zhou, F. Qin, J. Su, J. Liao, H. Xu, J. Food, Agric. Environ., 9, 1012 (2011)

13. H. Kim, J. Yang, J. Lee, J. Park, K. Kim, B. Lim, G. Lee, S. Lee, D. Shin, Y. Lim, Environ. Health Toxicol., 29, 1 (2014)

14. Department of Safety and Health, Guidelines On Occupational Safety And Health For Working With Video Disply Units (2003)

15. ICOP, Industry Code Of Practice On Indoor Air Quality (2010)

16. Jabatan Meteorologi Malaysia, Batu Pahat Monthly Max TT Min TT Max RH Min RH 2011 (2013)

17. P.J. Aphalo, The Plant Photobiology Notes, 1, 39 (2006)

18. A. Devkota, P.K. Jha, Middle-East J. Sci. Res., 5, 230 (2010)

19. M.D. Burchett, F. Torpy, L. De Filippis, J. Brennan, P.J. Irga, University of Technology (2011)

20. Argus, Argus Control Systems Ltd. (2010)

21. D.R. Taub, J.R. Seemann, J.S. Coleman, Plant Cell Environ., 23, 649 (2000)

22. G. Oquist, V.M. Hurry, N. Huner, Plant Physiol., 101, 1 (1993)

23. D.J. Allen, D.R. Ort, Trends Plant Sci., 6, 1 (2001)

24. W. Yamori, K. Hikosaka, D.A. Way, Photosynth. Res. 119.1 (2014)

25. J.L. Quero, R. Villar, T. Marañón, R. Zamora, D. Vega, L. Sack, Funct. Plant Biol., 35, 8 (2008)

26. F.R. Torpy, P.J. Irga, M.D. Burchett, Urban For. Urban Green., 13, 2 (2014)

27. B.C. Wolverton, How to Grow Fresh Air: 50 Houseplants that Purify Your Home Or Office (Penguin Books, 1997)

28. K. Omar-Hor, 1001 Plants in Singapore, (2006)

29. A. Drozak, E. Romanowska, Biochim. Biophys. Acta - Bioenerg., 1757, 11 (2006)

30. Jabatan Perdana Menteri Malaysia, Surat Pekeliling Am Bilangan 2 Tahun 2014 (2014)

31. M. Dela Cruz, J. H. Christensen, J.D. Thomsen, R. Muller, Env. Sci Pollut Res, 21, 13909 (2014)

32. Y.J. Liu, Y.J. Mu, Y.G. Zhu, H. Ding, N. Crystal Arens, Atmos. Environ., 41, 3 (2007)

33. D. Whiting, M. Roll, L Vickerman. Colorado State University (2014)

34. F.J. Sterck, R.A. Duursma, R.W. Pearcy, F.Valladares, M. Cieslak, M. Weemstra, , J. Ecol., 101, 4 (2013)

35. A. Field, Discovering Statistics Using IBM SPSS Statistics: And Sex and Drugs and Rock 'n' Roll (2013)

36. S. Schornack, E. Huitema, L.M. Cano, T.O. Bozkurt, R. Oliva, M. Van Damme, S. Schwizer, S. Raffaele, A. Chaparro-Garcia, R. Farrer, M. E. Segretin, J. Bos, B. J. Haas, M.C. Zody, C. Nusbaum, J. Win, M. Thines, S. Kamoun, Mol. Plant Pathol.,10, 6 (2009) 